Egyptian Journal of Aquatic Biology \& Fisheries

Zoology Department, Faculty of Science,

Ain Shams University, Cairo, Egypt.

ISSN $1110-6131$

Vol. 24(5): 323 - 339 (2020)

www.ejabf.journals.ekb.eg

\title{
Assessment of weather and climate variability over Western Harbor of Alexandria, Egypt
}

\section{Badea M. B. Mahfouz ${ }^{1}$, Alaa G. M. Osman ${ }^{2 *}$,Samy A. Saber ${ }^{3}$, Hassan M. M. Kanhalaf- Allah $^{1}$}

1. Marine Biology and Ichthyology Branch, Zool. Dept., Fac. Sci., Al-Azhar Univ., Cairo, Egypt

2. Marine Biology and Ichthyology Branch, Zool. Dept., Fac. Sci., Al-Azhar Univ., Assiut

Branch, Assiut, Egypt.

3. Zool. Dept., Fac. Sci., Al-Azhar Univ., Cairo, Egypt.

*Corresponding Author: agosman@azhar.edu.eg

\section{ARTICLE INFO}

Article History:

Received: July 13, 2020

Accepted: July 28, 2020

Online: July 30, 2020

\section{Keywords:}

Meteorological

conditions,

Climate variability,

Western Harbor,

Alexandria,

Egypt.

\begin{abstract}
The management of any harbor depends primarily on meteorological conditions. This study aimed to analyze the meteorological conditions over Western Harbor of Alexandria, using meteorological data recorded on an hourly basis from the automated weather station in the harbor from January 2007 to December 2018. The results revealed a general trend of a slight increase in the mean annual air temperature anomaly over the study period at a rate of $0.03^{\circ} \mathrm{C} /$ year. The mean annual sea-level pressure anomaly also showed an increasing trend at a rate of $0.011 \mathrm{~h} \mathrm{~Pa} /$ year. The dominant wind directions over the harbor were north-northwest during the study period. The lowest annual mean wind speed of $7 \mathrm{kt}$ occurred in 2007, while the highest wind speed of $11 \mathrm{kt}$ occurred in 2010. There was a trend of an increase in the mean annual wind speed anomaly at a rate of $0.12 \mathrm{kt} /$ year. In addition, there was a general trend of an increase in the mean annual relative humidity anomaly at a rate of $0.219 \% / y e a r$. Four, six, eight, and ten extreme values were detected for air temperature, sea-level pressure, wind speed, and relative humidity, respectively. However, oceanographic parameters should also be examined to strengthen our findings. Nonetheless, mitigation and awareness plans should be prepared and implemented for the harbor.
\end{abstract}

\section{INTRODUCTION}

The climate system is a complicated system consisting of five major interacting components: the land surface, the biosphere, the atmosphere, the hydrosphere, and the cryosphere (IPCC, 2001). This system is influenced by various external forcing mechanisms, including different anthropogenic activities and solar radiation from the sun. There are two types of change in the climate system: climate change and climate variability: climate variability concerns changes that occur within smaller timeframes, 
such as a month, season or year, and climate change includes changes that occur over a longer period, typically over decades or longer (IPCC, 2012 and Tonbol et al., 2018).

Climate changes are evident in different kinds of phenomena globally, including higher air temperatures, more extensive dry regions, more frequent and intense extreme weather with vast changes in rainfall patterns, increased ocean acidity, warmer oceans, and accelerated rates of sea-level rise, with different rates of change among regions (IPCC, 2007). Depending on the land surface, evapotranspiration and the carbon cycle affect the climate in different ways (Akinsanola \& Ogunjobi, 2014).

Knowledge of climate variability according to historical and long-term meteorological records at different temporal and spatial scales is important to understand the nature of different climate systems and their impact on the environment and society (Oguntunde et al., 2012 and Tonbol $\boldsymbol{e t}$ al., 2018). The climate of a location can be easily understood in terms of seasonal or annual averages in temperature and precipitation (Akinsanola \& Ogunjobi, 2014 and Tonbol et al., 2018).

In the twenty-first century, the Mediterranean region is one of the "hot spots" exposed to experience major climatic changes due to the global increase in greenhouse gas concentrations (Marriotti, 2011 and Tonbol et al., 2018). The relationship between air temperature and the fluctuation of the sea surface temperature in the eastern Mediterranean was examined by Repapis \& Philandras (1988), determining trends in variability over one hundred years. The same approach was taken by Metaxas $\boldsymbol{e t}$ al . (1991) for the whole Mediterranean basin using a data series that extended from 1873 to 1989. Their results exhibited that trends and fluctuations in air temperature are highly affected by local differences and regional changes. Significant positive trends in Malta and Tripoli and a negative trend in Amman were observed in air temperature from eight meteorological stations in the Eastern Mediterranean basin (Hasanean, 2001). Air temperature data in Turkey during the period 1929-1999 was evaluated by (Turkes et al., 2002), revealing spatiotemporal patterns of long-term trends, change points, and significant warming and cooling periods. In addition, Maiyza et al. (2011) detected a general decrease of $0.01^{\circ} \mathrm{C} /$ year in monthly air temperature anomalies from 1958 to 1990 in the southeastern Mediterranean Sea. Tonbol and El-Geziry (2015) concluded that variations in the daily sea surface temperature in the southeastern Mediterranean Sea are more related to variations in air temperature than wind speed (Tonbol et al., 2018).

Harbors play a substantial role in commerce, as promoters of economic growth, for global transportation, and for the development of global trade (World Bank, 2010, Becker et al., 2012 and Tonbol et al., 2019). Climate variability and change disproportionately affects harbors-based economies, depending on their geographic location and the adaptive capacities of the communities in which they are located (Becker et al., 2012 and Tonbol $\boldsymbol{e t}$ al., 2019). Climate variability and change can result in varying degrees of business interruption in harbors, including business closure in the most severe circumstances (Chhetri et al., 2015). Harbors must forestall the impacts of climate change and its effects, such as sea-level rise, increased flooding, high winds, storm surges, and more frequent extreme storm events to remain well organized (Hallegatte et al., 2011, Asariotis \& Benamara, 2012 and Tonbol et al., 2019). As harbors are located on coastlines, they are vulnerable to changes in climate driving factors, such as air temperature, wind regimes, atmospheric pressure, and relative 
humidity. Harbor activities and operations are strongly dependent on these meteorological parameters (Sánchez-Arcilla et al., 2016 and Tonbol et al., 2019).

The current management protocols of harbors do not yet consider the impacts of potential climate change on their own operations (Becker et al., 2012). The available studies addressing the effects of climate change on harbors (e.g., Hanson et al., 2011; Asariotis \& Benamara, 2012 and Sánchez-Arcilla et al., 2016) are limited compared to the numerous assessments of climate change impacts on coastal areas (Sierra et al., 2017).

Therefore, this study aimed to describe the characteristics of air temperature, sealevel pressure, wind regime, and relative humidity in Western Harbor of Alexandria, Egypt; using meteorological data recorded on an hourly basis from the automated weather station in the harbor from January 2007 to December 2018.

\section{MATERIALS AND METHODS}

\section{Study area}

Western Harbor of Alexandria (Fig. 1) is the major trade port of the North Coast of Egypt and it is managed by the Alexandria Harbor Authority. It has 87 quays with a total length of more than $40000 \mathrm{~m}$, and it is $7.4 \mathrm{~km}^{2}$ in surface area, $7 \mathrm{~km}$ in length, $2 \mathrm{~km}$ in maximum width, and its depth ranges from 5.5-16 m. It lies between the longitudes of $29^{\circ} 50.4^{\prime}$ and $29^{\circ} 52.5^{\prime} \mathrm{E}$ and latitudes of $31^{\circ} 9.6^{\prime}$ and $31^{\circ} 12^{\prime} \mathrm{N}$. The main entrance of the harbor is situated at the south-west side, between two beacons (Shiro \& Awed). It has a width of $450 \mathrm{~m}$ with a water depth varying from $14.6 \mathrm{~m}$ in the middle of the outlet to about $10.2 \mathrm{~m}$ toward the edges.

\section{Data and methods of analysis}

The used meteorological datasets were recorded on an hourly basis at Western Harbor, Alexandria, along the Egyptian Mediterranean Sea Coast (Fig. 1). The datasets covers a period of 12 years from 1 January 2007 to 31 December 2018. It comprises air temperature, atmospheric pressure, relative humidity, and wind regime, including speed and direction. The datasets of the different parameters are complete over the 12 years with no missing data. The meteorological data were measured and recorded by the Egyptian Hydrographic Department in the Egyptian Navy using an automatic weather station in Ras El-Teen (station No. 62317; longitude: $29^{\circ} 51^{\prime} 49^{\prime \prime}$ E and latitude: $31^{\circ} 11^{\prime} 50^{\prime \prime}$ $\mathrm{N}$. and height above sea level is $21.95 \mathrm{~m}$ ). 


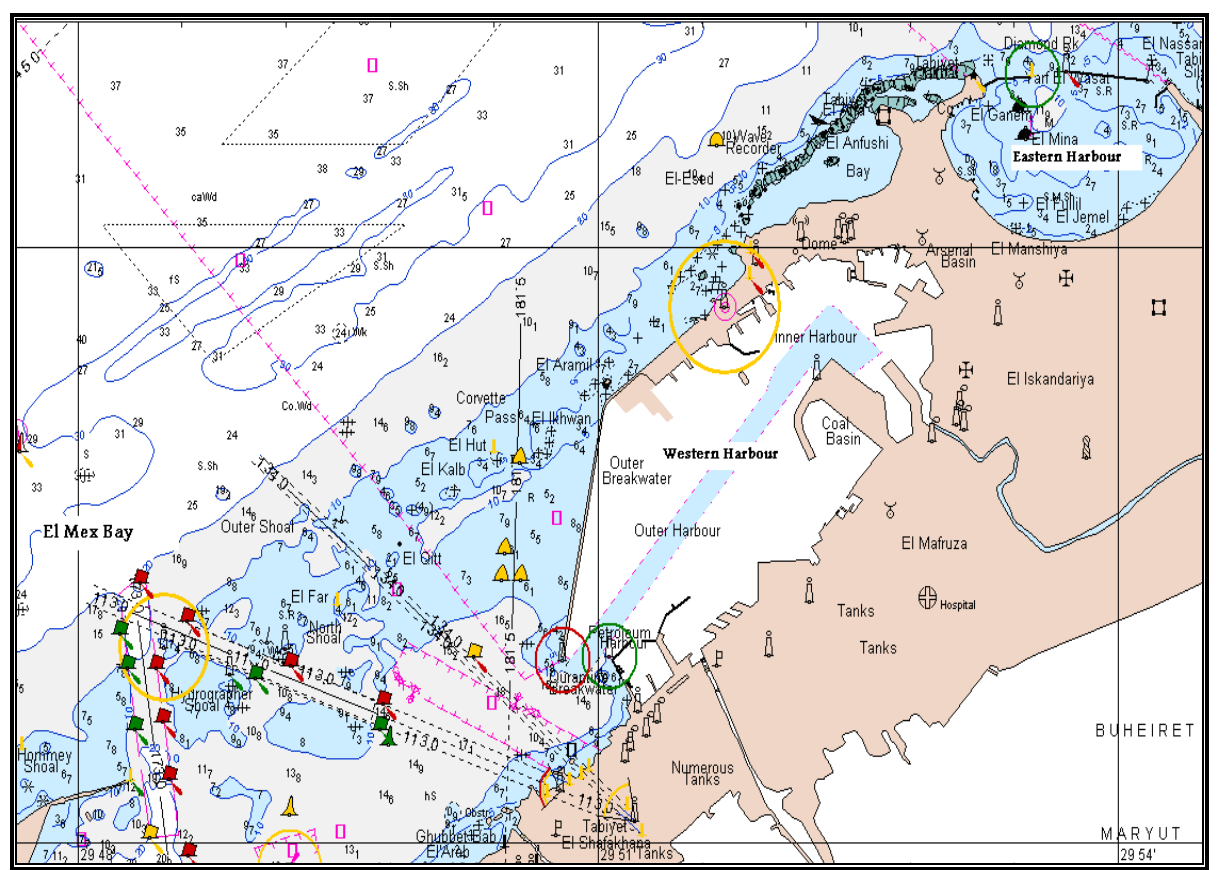

Fig. 1: A map of Egyptian Mediterranean Sea showing the location of Western Harbor and the automated weather station.

The minimum, maximum, mean values, monthly and annual means were calculated for each parameter to investigate seasonality and trends, respectively. Monthly and annual anomalies, which deviate from the monthly and annual means, respectively, were also calculated to detect any extreme event over Western Harbor during the period of investigation (Tonbol et al., 2019).

For example, the mean monthly air temperature over the period of investigation and the monthly mean air temperature for every month in the entire dataset were calculated. The deviation from the monthly mean was computed on a monthly basis to express the mean monthly air temperature anomaly (MMATA) (Tonbol $\boldsymbol{e t}$ al., 2018), using an equation:

$$
\Delta T=T-T_{m}
$$

Where,

$\Delta \mathrm{T}$ is the MMATA $\left({ }^{\circ} \mathrm{C}\right), \mathrm{T}$ is the mean monthly air temperature $\left({ }^{\circ} \mathrm{C}\right.$, mean for a specific month in a given year), and $\mathrm{Tm}$ is the monthly mean air temperature $\left({ }^{\circ} \mathrm{C}\right.$, mean for a specific month over 2007-2018).

The statistical differences between the different years for each investigated parameter were tested using analysis of variance (ANOVA) in SPSS $®$ with significance at $\mathrm{p}<0.05$.

\section{RESULTS}

\section{Air temperature}


The highest temperature recorded in the Alexandria Western Harbor data was $41^{\circ} \mathrm{C}$ during June 2010 , and the lowest temperature was $7^{\circ} \mathrm{C}$ during February 2015 with an average temperature of $21.8^{\circ} \mathrm{C}$ (Fig. 2). Air temperature fluctuated seasonally, recording a maximum average of $36.6^{\circ} \mathrm{C}$ during summer and a minimum average of $8.2^{\circ} \mathrm{C}$ during winter. The average maximum temperature was $34.7^{\circ} \mathrm{C}$ and the average minimum temperature was $14.7^{\circ} \mathrm{C}$.

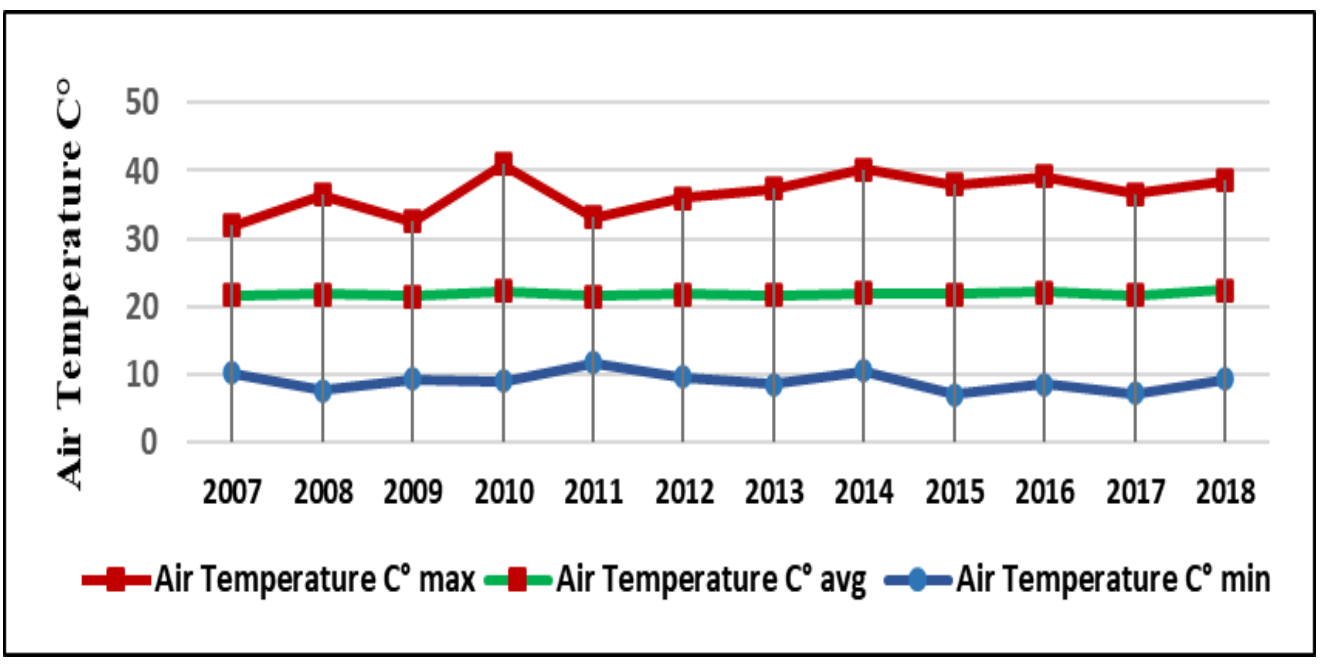

Fig. 2. Minimum, maximum, and mean annual air temperature over Western Harbor from 2007 to 2018.

The MMATA ranged between $-1.89^{\circ} \mathrm{C}$ (November 2011) and $1.6^{\circ} \mathrm{C}$ (April 2016). The equation that expressed changes in the MMATA at Western Harbor is

$$
\mathrm{Y}=0.002 \mathrm{X}-\mathbf{0 . 1 5} ; \mathrm{r}=\mathbf{0 . 1 1}
$$

This equation indicates that there was a very slight increase in the MMATA with a rate of $0.002^{\circ} \mathrm{C} /$ month. Four extremes were detected from the distribution of the MMATA (Fig. 3), two of which were positive: February $2010\left(1.48^{\circ} \mathrm{C}\right)$ and April 2016 $\left(1.57^{\circ} \mathrm{C}\right)$, and the other two were negative: February $2008\left(-1.53^{\circ} \mathrm{C}\right)$, November 2011 $\left(-1.90^{\circ} \mathrm{C}\right)$.

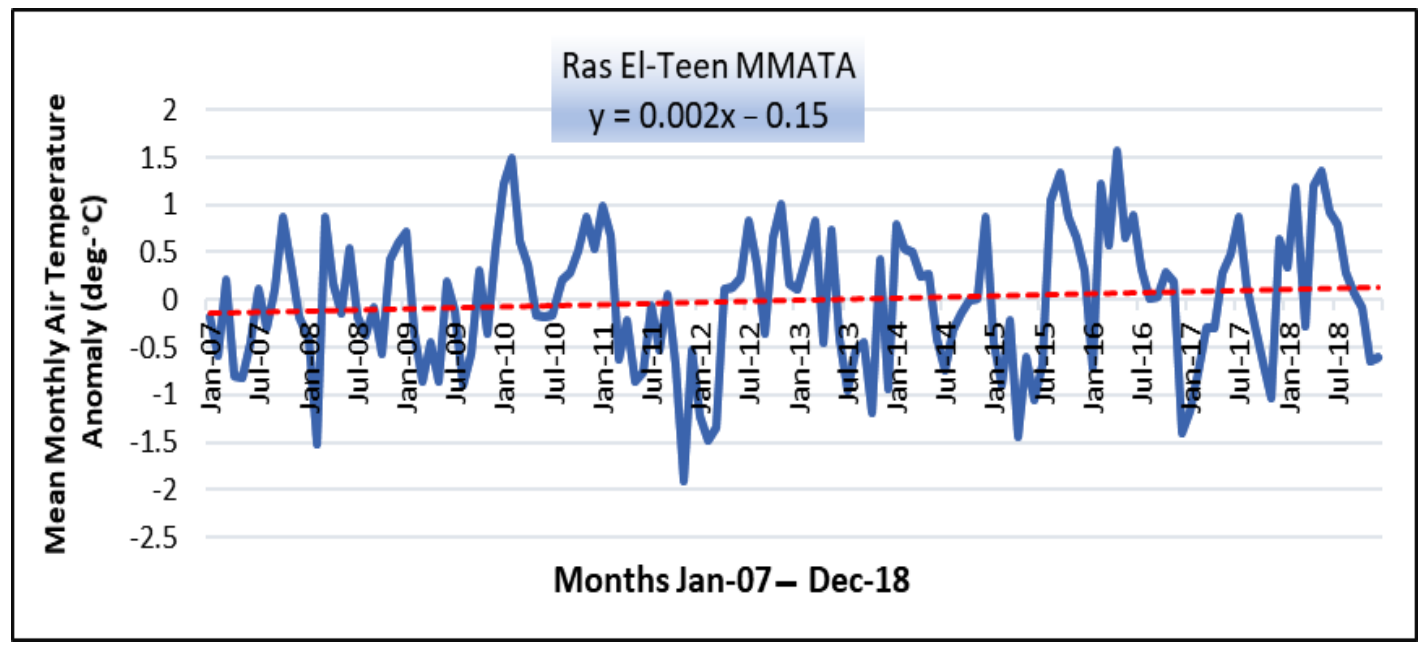


Fig. 3. Distribution and trend of the mean annual air temperature anomaly over Western Harbor, 20072018

For mean annual air temperature, 2011 had the lowest $\left(21.5^{\circ} \mathrm{C}\right)$ among the 12 years of investigation and 2018 had the highest $\left(22.4^{\circ} \mathrm{C}\right)$ mean annual air temperature. The mean annual air temperature anomaly (MAATA; Fig. 4) reflected a general increase in the MAATA over the period of the investigation that can be expressed by the equation

$$
\mathrm{Y}=\mathbf{0 . 0 3 2 2} \mathrm{X}-\mathbf{0 . 2 0} ; \mathrm{r}=\mathbf{0 . 4 2}
$$

This equation indicates that MAATA increased with a rate of $0.032^{\circ} \mathrm{C} / \mathrm{year}$. Two years, 2010 and 2018 were significantly different from all other years under investigation, according to the ANOVA (Table 1).

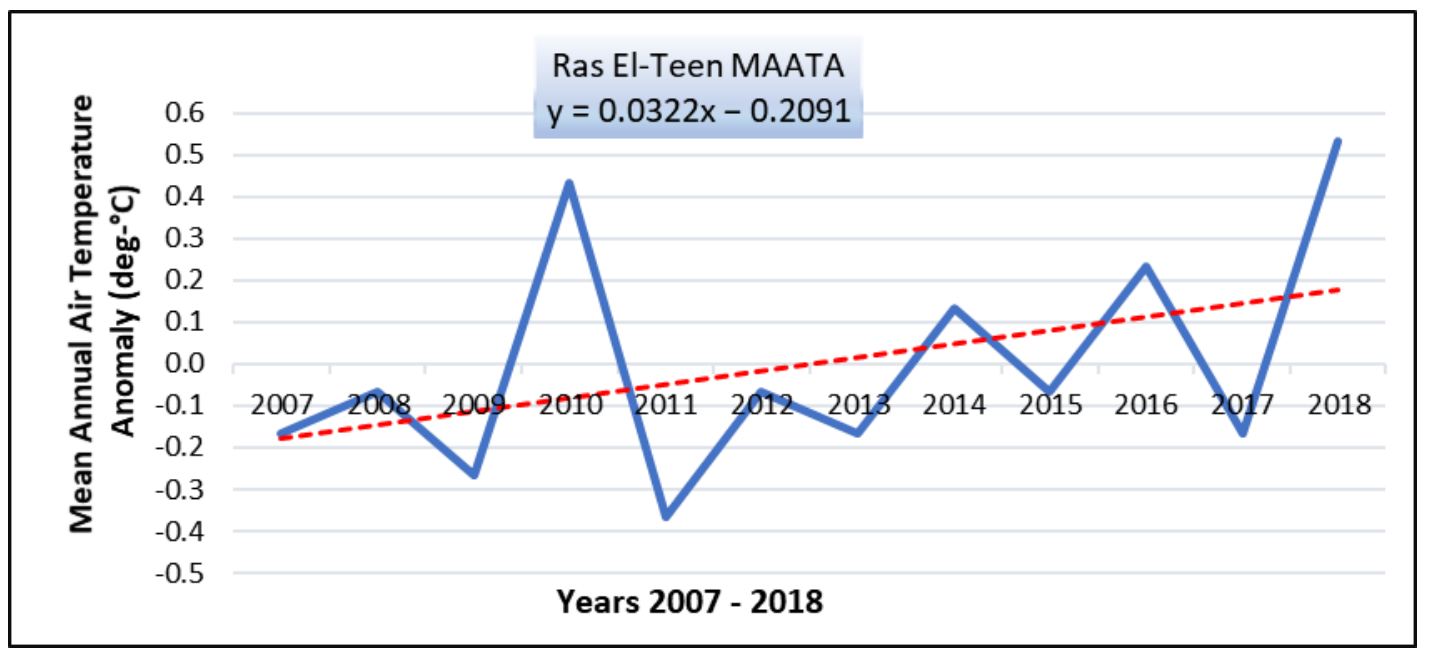

Fig. 4. Distribution and trends of the mean annual air temperature anomaly over Western Harbor, 20072018

Table 1. Statistical analysis of the annual air temperature over Western Harbor from January 2007 to December 2018

\begin{tabular}{|c|c|c|c|c|}
\hline \multirow{2}{*}{ Year } & \multicolumn{5}{|c|}{ Air temperature $\left({ }^{\circ} \mathbf{C}\right)$} \\
\hline 2007 & Mean & Min & Max & Std.Dev. \\
\hline 2008 & 21.7 & 10.2 & 32 & 4.8 \\
\hline 2009 & 21.8 & 7.7 & 36.4 & 5.2 \\
\hline 2010 & 21.6 & 9.3 & 32.6 & 4.6 \\
\hline 2011 & 22.3 & 9 & 41 & 4.6 \\
\hline 2012 & 21.5 & 11.8 & 33.2 & 4.6 \\
\hline 2013 & 21.8 & 9.6 & 36 & 5.2 \\
\hline 2014 & 21.7 & 8.6 & 37.4 & 4.6 \\
\hline 2015 & 22 & 10.6 & 40.2 & 4.3 \\
\hline 2016 & 21.8 & 7 & 38 & 5.1 \\
\hline 2017 & 22.1 & 8.6 & 39.2 & 4.9 \\
\hline 2018 & 21.7 & 7.2 & 36.6 & 4.9 \\
\hline
\end{tabular}




\section{Sea-level pressure:}

The monthly mean sea-level pressure over Western Harbor from January 2007 to December 2018 ranged between 1005.9 hectopascals (hpa) (July 2012) and $1022.2 \mathrm{hPa}$ (January 2007), with an overall average of $1013.4 \mathrm{hPa}$. The mean monthly sea-level pressure anomaly (MMSLPA) ranged from $-3.4 \mathrm{hPa}$ (March 2010) to $4.7 \mathrm{hPa}$ (February 2008). Six extreme values were detected from, of which four were positive: $3.9 \mathrm{hPa}$ (January 2007), $4.7 \mathrm{hPa}$ (February 2008), $3.5 \mathrm{hPa}$ (March 2011), and $3.3 \mathrm{hPa}$ (March 2012; Fig. 5). The two negative extreme anomalies were $-2.7 \mathrm{hPa}$ in May 2007 and -3.4 $\mathrm{hPa}$ in March 2008. The linear trend of the MMSLPA reflected a general increase with a rate of $0.001 \mathrm{hPa} /$ month and can be mathematically expressed by the equation

$$
y=0.001 x-0.0732 ; r=0.42
$$

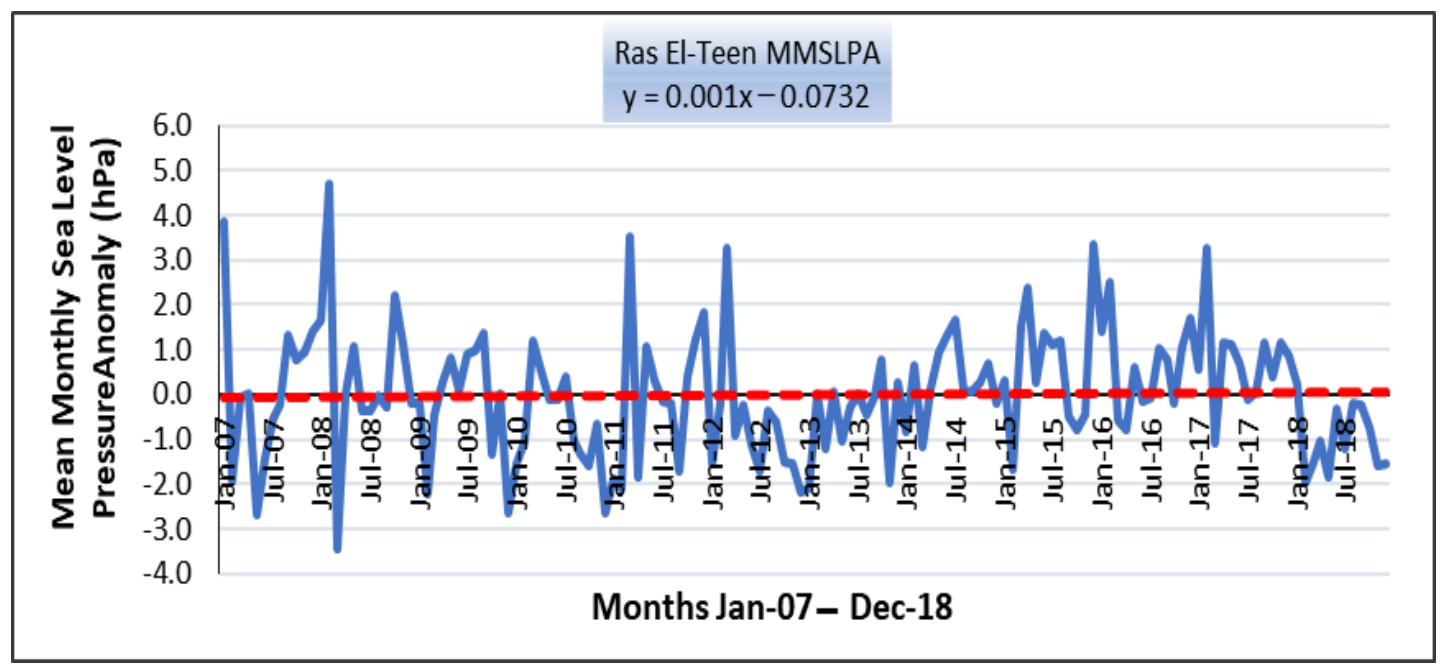

Fig. 5. Distribution and trend of the mean monthly sea-level pressure anomaly over Western Harbor, 2007-2017

The annual normal values of atmospheric pressure in this study were different between years. The recorded atmospheric pressure values from 2007-2018 indicated that the highest value of 1032.3 hpa was recorded in 2007, having a mean annual atmospheric pressure of $1013.5 \mathrm{hpa}$. However, the lowest atmospheric pressure value of $998.2 \mathrm{hpa}$ was recorded in 2018 with an annual mean record of 1012.4 hpa (Fig. 6).

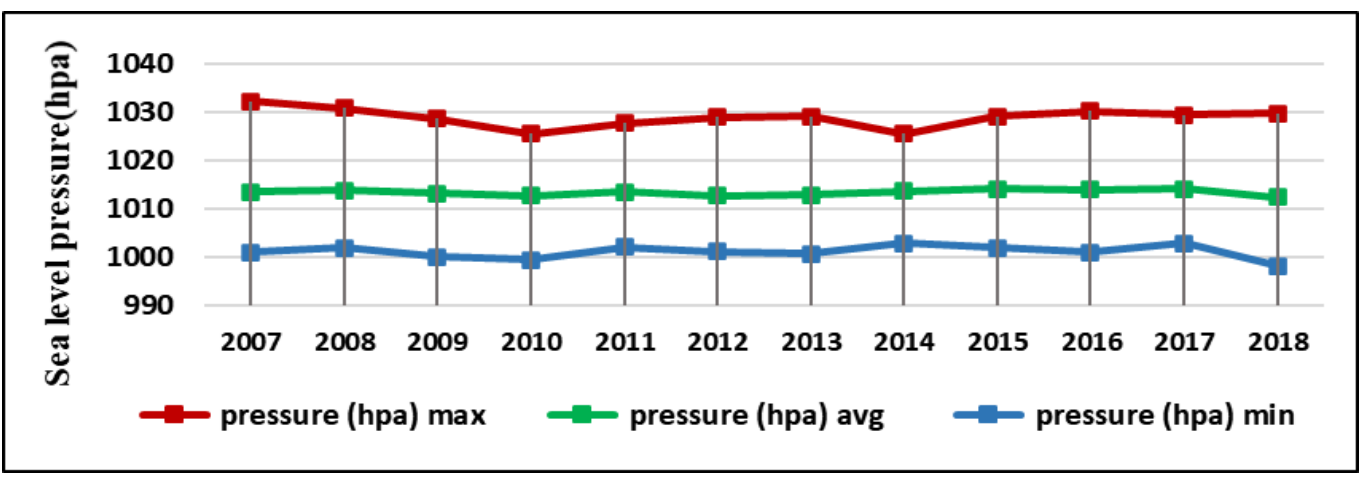

Fig. 6. Minimum, maximum, and mean annual sea-level pressure over Western Harbor from 2007 to 2018 . 
The minimum annual mean sea-level pressure was $1012.4 \mathrm{hPa}$ in 2018 , and the maximum was $1014.2 \mathrm{hPa}$ in 2017 , with an average of $1013.4 \mathrm{hPa}$. However, the mean annual sea-level pressure anomaly (MASLPA) ranged between $-0.98 \mathrm{hPa}$ in 2018 and $0.75 \mathrm{hPa}$ in 2017 (Fig. 7).

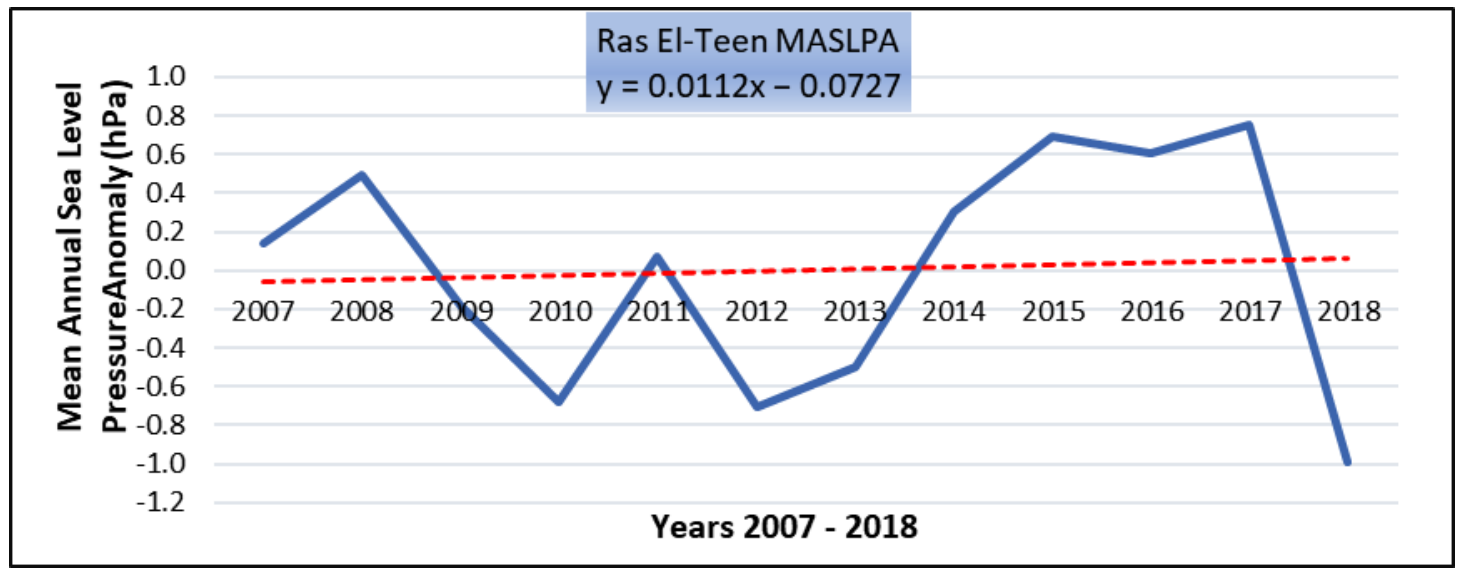

Fig. 7. Distribution and trends of the mean annual sea-level pressure anomaly over Western Harbor, 2007-2018.

The MASLPA also showed a general trend of increase, which can be mathematically expressed by the equation

$$
\mathrm{y}=0.011 \mathrm{x}-0.0727 ; \mathrm{r}=0.07
$$

The rate of increase in MASLPA was $0.11 \mathrm{hPa} /$ year. The ANOVA showed that in 2018 the recorded sea-level pressure was significantly different to that of the other 11 years (Table 3).

Table 2. Statistical analysis of the annual sea level pressure over Western Harbor from January 2007 to December 2018

\begin{tabular}{|c|c|c|c|c|}
\hline \multirow{2}{*}{ Year } & \multicolumn{4}{|c|}{ Sea level pressure (hPa) } \\
\cline { 2 - 5 } & Mean & Min & Max & Std.Dev. \\
\hline 2007 & 1013.5 & 1001.1 & 1032.3 & 5.4 \\
\hline 2008 & 1013.9 & 1002.0 & 1030.8 & 5.2 \\
\hline 2009 & 1013.2 & 1000.1 & 1028.7 & 4.3 \\
\hline 2010 & 1012.7 & 999.6 & 1025.6 & 4.4 \\
\hline 2011 & 1013.5 & 1002.1 & 1027.8 & 4.9 \\
\hline 2012 & 1012.7 & 1001.2 & 1028.9 & 4.9 \\
\hline 2014 & 1012.9 & 1000.7 & 1029.2 & 4.5 \\
\hline 2015 & 1013.7 & 1002.9 & 1025.5 & 4.3 \\
\hline 2016 & 1014.1 & 1002.0 & 1029.2 & 4.8 \\
\hline 2017 & 1014.0 & 1001.1 & 1030.2 & 5.0 \\
\hline 2018 & 1014.2 & 1002.9 & 1029.5 & 5.0 \\
\hline
\end{tabular}




\section{Wind regime}

The dominant direction of wind blowing over the harbor during the period of investigation was north-northwest (NNW).

The monthly mean wind speed varied between $5.3 \mathrm{kt}$ (August 2007) and $14.2 \mathrm{kt}$ (January 2018), with an overall mean wind speed of $10.1 \mathrm{kt}$. The mean monthly wind speed anomaly (MMWSA) varied between $-5.8 \mathrm{kt}$ in July 2007 and $4.1 \mathrm{kt}$ in January 2018 (Fig. 8). This increase in MMWSA had a rate of $0.01 \mathrm{kt} / \mathrm{month}$ and can be mathematically expressed by the equation

$$
\mathrm{y}=0.0101 \mathrm{x}-0.7275 ; \mathrm{r}=0.25
$$

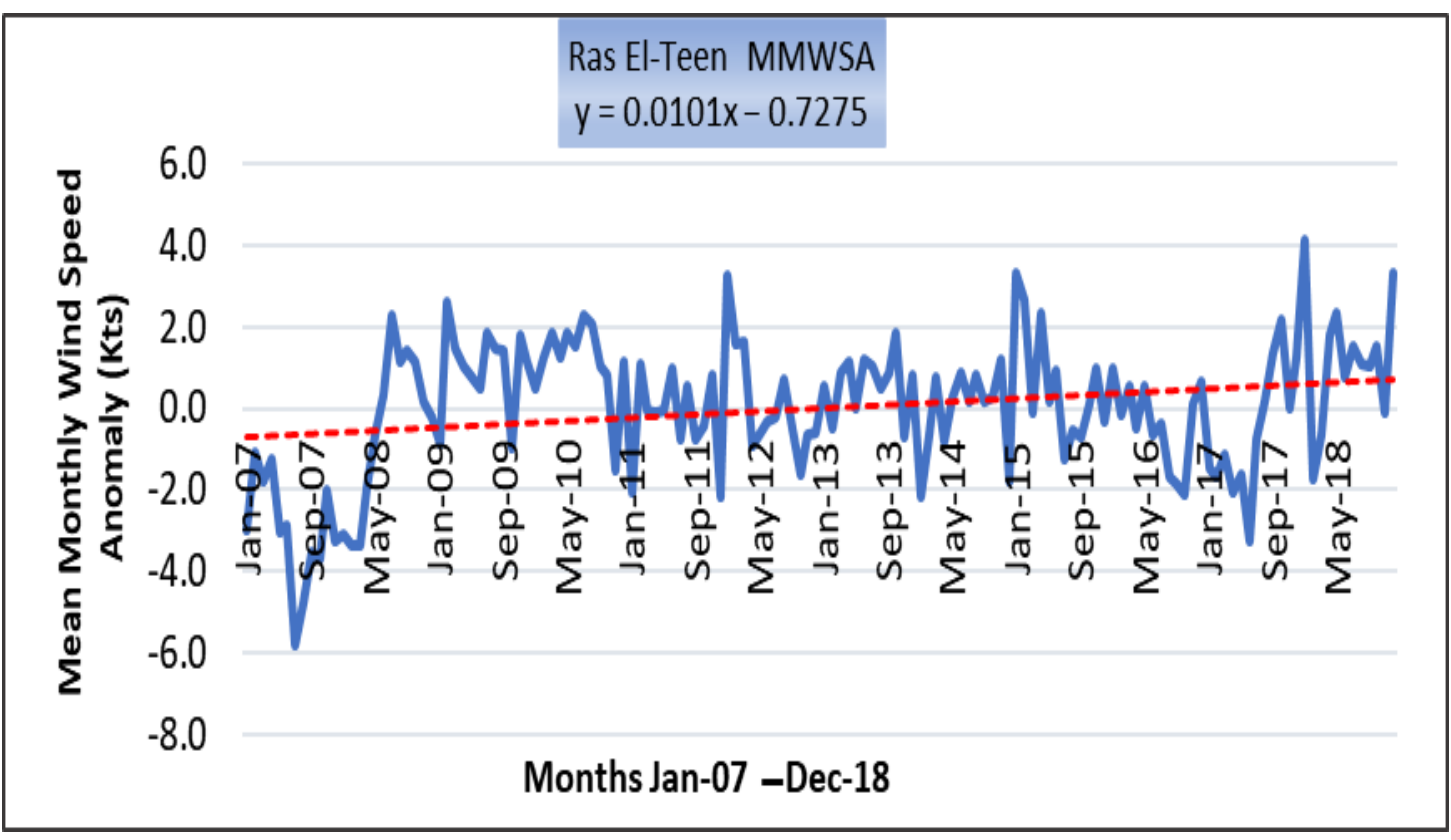

Fig. 8. Distribution and trend of the mean monthly wind speed anomaly over Western Harbor, 2007-2018.

From the MMWSA distribution, eight extremes were observed, four of which were positive. The positive MMWSA extremes were $3.3 \mathrm{kt}$ (January 2012), $3.3 \mathrm{kt}$ (January 2015), $4.1 \mathrm{kt}$ (January 2018), and $3.3 \mathrm{kt}$ (December 2018). The negative extremes were $-5.8 \mathrm{kt}$ (July 2007), -4.8 kt (Augustus 2007), -3.7 kt (October 2007), and -3.4 kt (February 2008).

The mean annual wind speed was lowest (7 kt) in 2007 and highest $(11.4 \mathrm{kt})$ in 2018. The mean annual wind speed anomaly (Fig. 9) ranged from $-3.03 \mathrm{kt}$ (2007) to 1.28 $\mathrm{kt}$ (2018). It had an increasing trend with a rate of $0.125 \mathrm{kt} / \mathrm{year}$. It can be expressed as

$$
\mathrm{y}=0.1257 \mathrm{x}-0.8168 ; \mathrm{r}=0.39
$$

Results in Table (4) summarize the statistical analysis of the annual wind speed over Western Harbor from January 2007 to December 2018. 


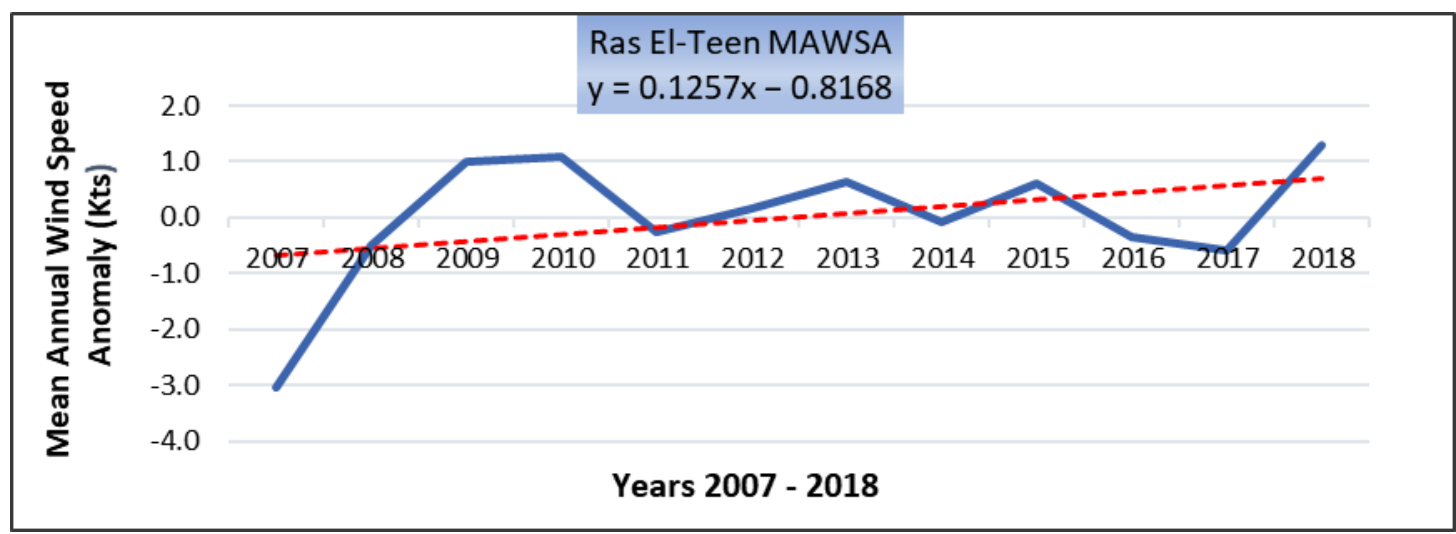

Fig. 9. Distribution and trend of the mean annual wind speed anomaly over Western Harbor, 2007-2018

Table 3. Statistical analysis of the annual wind speed over Western Harbor from January 2007 to December 2018

\begin{tabular}{|c|c|c|c|c|}
\hline \multirow{2}{*}{ Year } & \multicolumn{4}{|c|}{ Wind speed (Kts) } \\
\hline & Mean & Min & Max & Std.Dev. \\
\hline 2007 & 7.0 & 0.0 & 27 & 4.2 \\
\hline 2008 & 9.6 & 0.0 & 34 & 4.9 \\
\hline 2009 & 11.1 & 0.0 & 40 & 5.5 \\
\hline 2010 & 11.2 & 0.0 & 46 & 5.8 \\
\hline 2011 & 9.8 & 0.0 & 35 & 5.1 \\
\hline 2012 & 10.2 & 0.0 & 34 & 5.5 \\
\hline 2013 & 10.7 & 0.0 & 39 & 5.1 \\
\hline 2014 & 10.0 & 0.0 & 29 & 4.3 \\
\hline 2015 & 10.7 & 0.0 & 38 & 5.2 \\
\hline 2016 & 9.7 & 0.0 & 38 & 5.4 \\
\hline 2017 & 9.5 & 0.0 & 36 & 4.8 \\
\hline 2018 & 11.4 & 0.0 & 38 & 4.8 \\
\hline
\end{tabular}

\section{Wind pattern}

The average wind speed was $10.1 \mathrm{kt}$ while the maximum was $46 \mathrm{kt}$ in 2010 and $30.7 \%$ of the blowing wind was NNW (Figs. 10 and 11). The frequency of calm winds from 0 to less than $0.9 \mathrm{kt}$ speed was $1.1 \%$ and from 11.08 to $17.11 \mathrm{kt}$ was $33.2 \%$, with extreme winds occurring in storms more than $21.58 \mathrm{kt}$ being $2.9 \%$ during the pass of depressions (Table 5).

A significantly different wind speed was recorded between years excluding 2007, 2008, and 2017. 




Fig. 10. Wind rose over Western Harbor during the study period

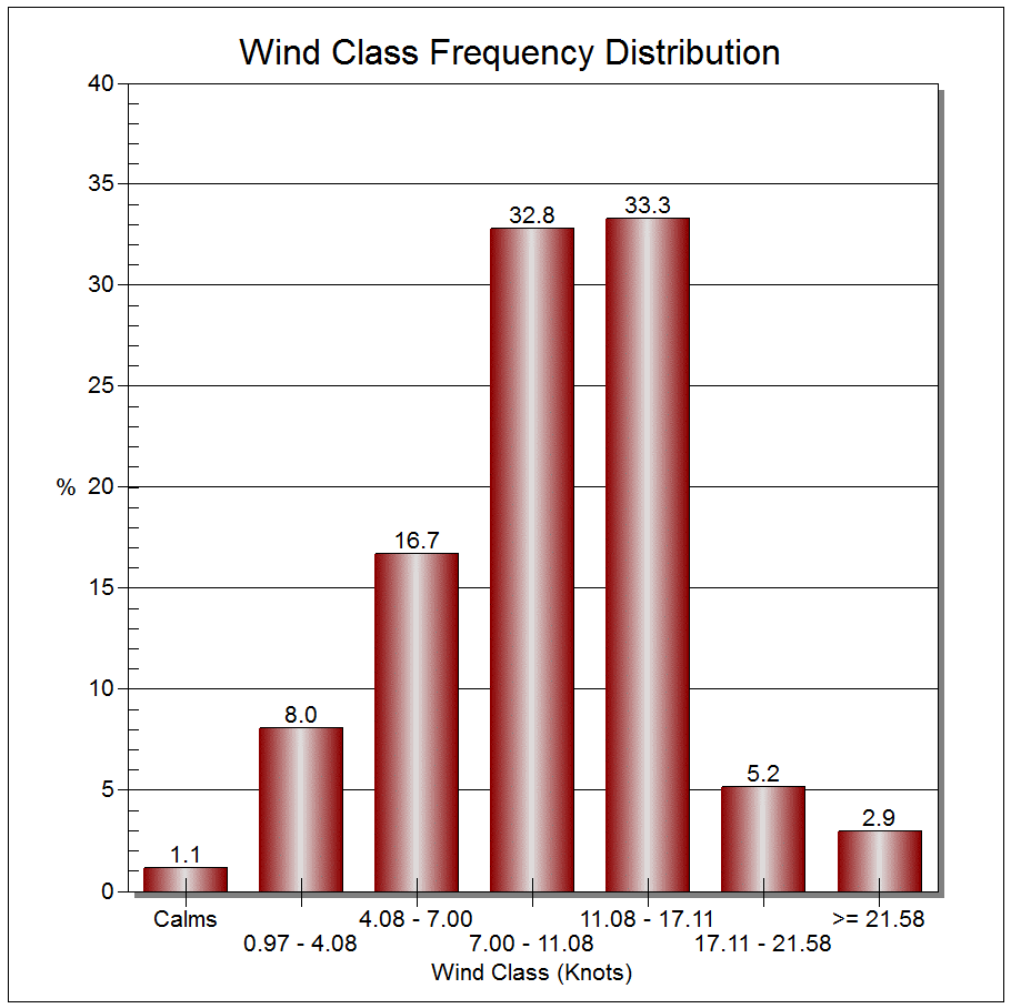

Fig. 11 Wind speed frequency distribution during the study period 
Table 4. Wind speed and direction frequency over Western Harbor from January 2007 to December 2018

\begin{tabular}{|c|c|c|c|c|c|c|c|}
\hline $\begin{array}{c}\text { Directions/ Wind } \\
\text { Classes (Knots) }\end{array}$ & $\mathbf{1 - 4}$ & $\mathbf{4 - 7}$ & $\mathbf{7 - 1 1}$ & $\mathbf{1 1 - 1 7}$ & $\mathbf{1 7 . - 2 1 . 5 8}$ & $\mathbf{> = 2 1 . 5 8}$ & $\begin{array}{c}\text { Total } \\
(\mathbf{\%})\end{array}$ \\
\hline $\mathbf{N}$ & 1.09 & 3.23 & 7.82 & 4.11 & 0.27 & 0.08 & $\mathbf{1 6 . 6 0}$ \\
\hline NNE & 0.83 & 2.02 & 3.33 & 1.48 & 0.06 & 0.01 & $\mathbf{7 . 7 2}$ \\
\hline ENE & 0.56 & 1.06 & 1.23 & 0.48 & 0.03 & 0.01 & $\mathbf{3 . 3 7}$ \\
\hline E & 0.78 & 1.28 & 1.41 & 0.67 & 0.06 & 0.00 & $\mathbf{4 . 2 0}$ \\
\hline ESE & 1.16 & 1.60 & 1.99 & 1.10 & 0.08 & 0.01 & $\mathbf{5 . 9 5}$ \\
\hline SSE & 0.88 & 1.00 & 0.95 & 0.40 & 0.04 & 0.00 & $\mathbf{3 . 2 7}$ \\
\hline S & 0.54 & 0.70 & 0.62 & 0.28 & 0.05 & 0.01 & $\mathbf{2 . 2 0}$ \\
\hline SSW & 0.22 & 0.39 & 0.50 & 0.41 & 0.09 & 0.07 & $\mathbf{1 . 6 7}$ \\
\hline WSW & 0.22 & 0.38 & 0.61 & 0.77 & 0.24 & 0.24 & $\mathbf{2 . 4 7}$ \\
\hline W & 0.27 & 0.64 & 1.30 & 2.21 & 0.68 & 0.75 & $\mathbf{5 . 8 5}$ \\
\hline WNW & 0.45 & 1.22 & 3.58 & 7.09 & 1.66 & 0.85 & $\mathbf{1 4 . 8 5}$ \\
\hline NNW & 1.04 & 3.14 & 9.43 & 14.27 & 1.92 & 0.91 & $\mathbf{3 0 . 7 1}$ \\
\hline Sub-Total & 8.03 & 16.68 & 32.78 & 33.27 & 5.16 & 2.93 & $\mathbf{9 8 . 8 6}$ \\
\hline Calms & & & & & & & $\mathbf{1 . 1 4}$ \\
\hline Missing & & & & & & & $\mathbf{0 . 0}$ \\
\hline Total & & & & & & & $\mathbf{1 0 0}$ \\
\hline
\end{tabular}

\section{Relative humidity}

The mean monthly relative humidity over Western Harbor ranged between $57.3 \%$ (January 2008) and 77.6\% (July 2009), with an overall mean of 68.7\% during the period of investigation.

The annual normal values of the relative humidity in this study from 2007-2018 indicate that the highest value of 99\% was recorded in 2008-2014 with an annual mean relative humidity of $64.9 \%$. However, the lowest value of $11 \%$ was recorded in 2009 (Fig. 12).

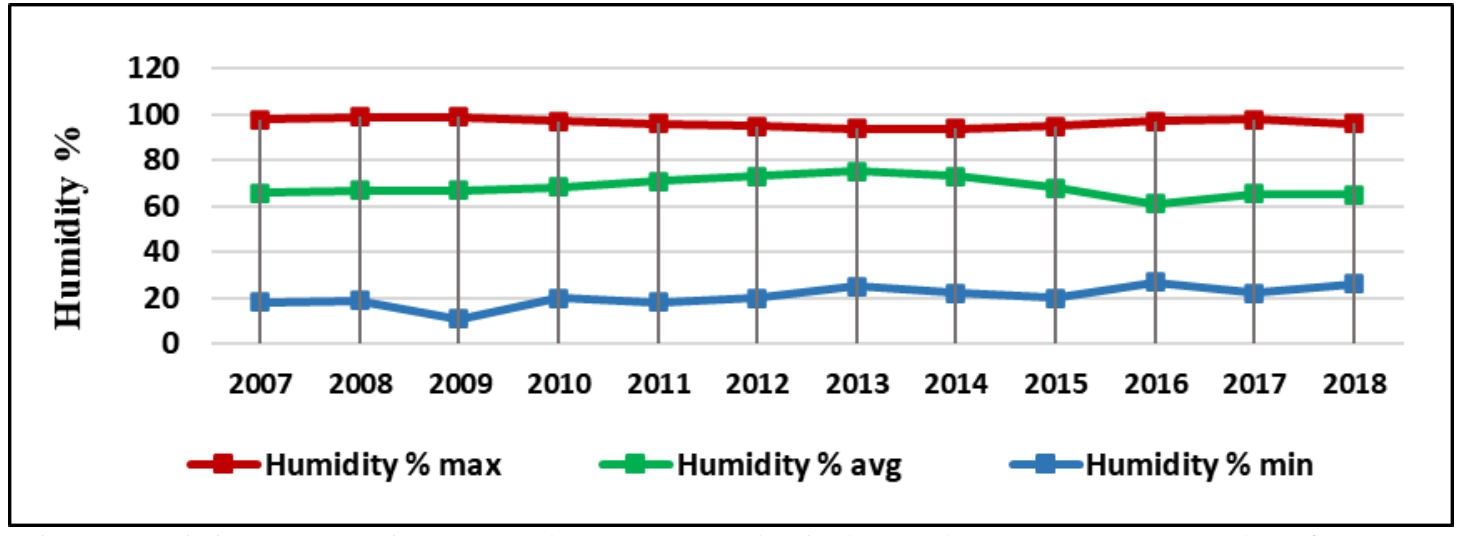

Fig. 12. Minimum, maximum, and mean annual wind speed over Western Harbor from 2007 to 2018.

The mean monthly relative humidity anomaly (MMRHA; Fig.13) ranged from $-8.4 \%$ (January 2008) to $6.9 \%$ (January 2014). The MMRHA had an increasing trend over the period of investigation, with a rate of $0.0191 \% /$ month. This linear trend can be mathematically expressed by the equation

$$
\mathrm{y}=0.0191 \mathrm{x}-1.0812 ; \mathrm{r}=0.28
$$


From the MMRHA distribution, 10 extreme values were detected, five of which were positive. The positive extremes were observed in October 2007 (7.4\%), October 2010 (5.7\%), October 2012 (7.7\%), November 2013 (5.4\%), and January 2014 (6.9\%).



Fig. 13. Distribution and trend of the mean monthly relative humidity anomaly over Western Harbor, 2007-2018.

The negative extremes were observed in March 2007 (5.8\%), April 2007 (5.5\%), September 2007 (7.5\%), January 2008 (8.4\%), and February 2008 (7.8\%).

The year 2007 had the lowest annual mean relative humidity (65\%), while 2013 had the highest (71\%). However, the mean annual relative humidity anomaly (MARHA) varied between $-3.9 \%$ in 2007 and $1.9 \%$ in 2013 (Fig. 14). The increasing linear trend of the MARHA can be expressed by the equation

$$
\mathrm{y}=0.219 \mathrm{x}-1.4237 ; \mathrm{r}=0.48
$$

The MARHA had a rate of 0.219\%/year from January 2007 to December 2018. The years 2007 and 2013 were the only two years showing a total significance in the recorded relative humidity with respect to other years (Table 6).

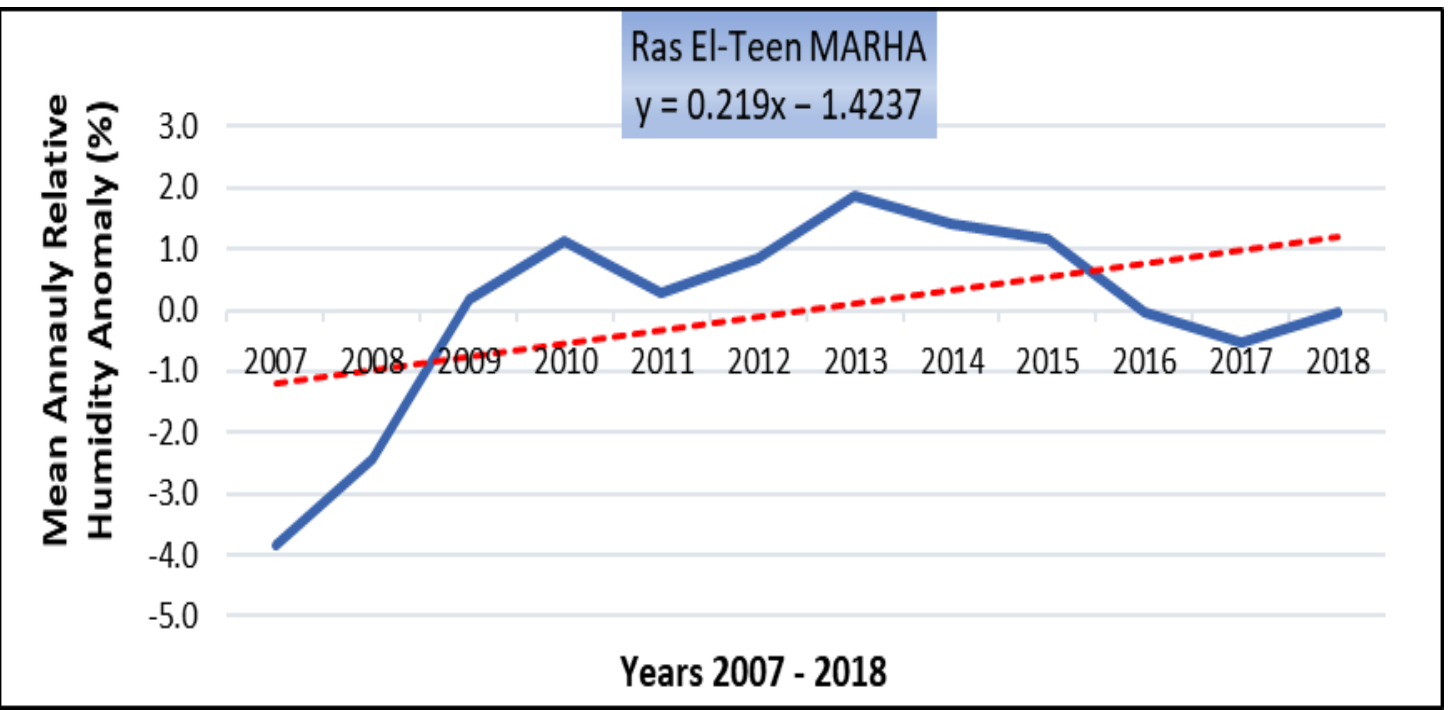

Fig. 14. Distribution and trend of the mean annual relative humidity anomaly over Western Harbor, 2007-2018 
Table 5. Statistical analysis of the annual relative humidity over Western Harbor from January 2007 to December 2018

\begin{tabular}{|c|c|c|c|c|}
\hline \multirow{2}{*}{ Year } & \multicolumn{4}{|c|}{ Relative humidity (\%) } \\
\hline & Mean & Min & Max & Std.Dev. \\
\hline 2007 & 65 & 30 & 89 & 8.3 \\
\hline 2008 & 66 & 11 & 99 & 11.3 \\
\hline 2009 & 69 & 16 & 97 & 11.7 \\
\hline 2010 & 70 & 15 & 98 & 11.8 \\
\hline 2011 & 69 & 20 & 96 & 9.5 \\
\hline 2012 & 70 & 26 & 98 & 10 \\
\hline 2013 & 71 & 20 & 96 & 10.7 \\
\hline 2014 & 70 & 18 & 99 & 9.8 \\
\hline 2015 & 70 & 20 & 96 & 9.7 \\
\hline 2016 & 69 & 21 & 99 & 10.1 \\
\hline 2017 & 68 & 22 & 97 & 10 \\
\hline 2018 & 69 & 21 & 98 & 10.1 \\
\hline
\end{tabular}

\section{DISCUSSION}

The economy relies on maritime transportation and sea-going trade to a considerable extent. Ports and the shipping industry are affected by climate variability. However, globally, many ports are still unaware of the likely pressures of climate variability and change, or they are slow to implement suitable adaptation actions. The effects of climate variability and change on harbors include sea-level rise, wind and storm regimes, extremely hot days, change in precipitation patterns, and flooding, effecting maritime operations, and activities (Tonbol et al., 2019). This paper highlights the changes in meteorological conditions over the most important Egyptian port along the Mediterranean Coast: Western Harbor. According to our knowledge, no available literature has been conducted on this topic for the Western Harbor. Varieties within the examined meteorological parameters play a vital part in deciding the impact of climate variability within the region of the harbor since its shoreline configuration and its services are in dynamic balance with the meteo-oceanographic patterns.

The current work is based on hourly data records of four meteorological parameters including air temperature, sea-level pressure, wind regime, and relative humidity from the automated weather station at Western Harbor: The dataset covers a period of 12 years (January 2007 to December 2018) with no missed data. The anomalies, which are deviations from the mean, were calculated for each parameter, to examine trends and detect any extreme values according Tonbol et al. (2019). Anomalies permit the elimination of external effects on the examined parameter and, therefore, lead to more convenient and reasonable conclusions on trends and behavior of change (Tonbol et al. 2019).

Over the period of examination, the detected temperature appeared slight patterns of increase $\left(0.002^{\circ} \mathrm{C} /\right.$ month $)$ and $\left(0.03^{\circ} \mathrm{C} /\right.$ year $)$. The observed increase in air temperature can influence, on a regional basis, the calculated mean sea level and the rate of sea-level rise at the harbor, and it can affect the storm development process (Tonbol et al., 2019). 
The maximum air temperature $\left(41^{\circ} \mathrm{C}\right)$ was recorded during June 2010 , and the minimum value $7^{\circ} \mathrm{C}$ was recorded during February 2015 with an average temperature of $21.8^{\circ} \mathrm{C}$. Along the Mediterranean Sea coast, seasonal variations in air temperate are related to the prevailing climate of the Mediterranean Sea, which is affected by both subtropical and mid-latitude weather systems. According to the Egyptian Metrological Organization records for the last century, the maximum and minimum values of temperature reach $38^{\circ} \mathrm{C}$ in summer and $8^{\circ} \mathrm{C}$ in winter (Hazem, 1999). The values we found were more extreme than this.

The sea-level pressure over Western Harbor tends to be ordinarily conveyed with regard to the detected air temperature. In any case, the sea-level pressure tended also to appear an expanding slant over the consider period on both monthly and annual basis with rates of $0.001 \mathrm{hPa} /$ month and $0.011 \mathrm{hPa} /$ year, respectively. The influence of sealevel pressure change is watched in changes in sea levels in the region of the harbor, and it is likely that more changes are expected in the future.

The wind regime over the Egyptian Mediterranean Coast is related to the prevailing wind of this region. The wind speed and direction varied diurnally and seasonally. The present study showed that the wind direction and frequency distribution of the wind class of the study area depended on variations in atmospheric pressure. The predominant wind in the study area was NNW, and the average wind speed was $11-17 \mathrm{kt}$ for $42.1 \%$ of the total wind. Extreme winds of $>22 \mathrm{kt}$ occurred during storms in a north to northeast and southerly direction. This variation in wind regime was controlled by the Azores anticyclone extension over the Libyan Desert and the North Atlantic depression entering the eastern Mediterranean area associated with cold Atlantic air masses. This cold air meets the warm and moist air of the Mediterranean area. Consequently, vertical instability and moving atmospheric perturbations, associated with meteorological fronts are generated. The traveling depressions, when associated with ridges of high pressure over the northwestern Libyan Desert, generate high waves and cause showers, thunderstorms, and rising sand or sandstorms, as mentioned by Elbessa (2011). The wind speed at Western Harbor tended to increase with time at rates of $0.01 \mathrm{kt} / \mathrm{month}$ and 0.12 kt/year. Any change in the wind speed and direction could affect the harbor's structural safety and functionality and impact on its services, e.g., ship berthing, goods loading and unloading, and crane operations (Tonbol et al. 2019).

Our results revealed a general increase in the trends of relative humidity on both a monthly and annual basis: $0.01 \% /$ month and $0.219 \% /$ year with a minimum value of $11 \%$ in 2008 and a maximum value of $99 \%$ in 2014.

In conclusion, the location of the western port geographically protects the port from the prevailing direction of winds (north or northwest) and generally affects the movement of water, such as waves, surface currents, and sea-level rise. The sheltered location of the harbor, which is secured by a six water vents (ash-toms) breakwater, seems to provide stable metrological conditions over Western Harbor, except when air depressions pass, where the wind speed increases by more than $22 \mathrm{kt}$, as this leads to the closure of the port and the suspension of maritime navigation in the port. Our results could contribute to informing safe maritime operations and activities over time. However, the oceanographic parameters of sea surface temperature, sea-level, surface currents, and waves should also be examined to confirm this stability. 


\section{REFERENCES}

Akinsanola, A.A. and Ogunjobi, K.O. (2014). Analysis of rainfall and temperature variability over Nigeria. Global Journal of Human-Social Science (B): Geography, Geosciences, Environmental Disaster Management., 14(3): 1-17.

Asariotis, R. and Benamara, H. (2012). Maritime transport and the climate change challenge. Earthscan/Routledge, Geneva, New York, UN., pp: 327.

Becker, A.; Inoue, S.; Fischer, M. and Schwegler, B. (2012). Climate change impacts on international seaports: knowledge, perceptions, and planning efforts among port administrators. Clim. Chang., 110(1): $5-29$.

Chhetri, P.; Corcoran, J.; Gekara, V.; Maddox, C. and McEvoy, D. (2015). Seaport resilience to climate change: mapping vulnerability to sea-level-rise. J. Spat. Sci., 60(1): $65-78$.

Elbessa, M. (2011). Investigation of waves current and sea level along Alexandria coastal water. M.Sc. Thesis, College of Maritime Transport and Technology Arab Academy for Science, Technology and Maritime Transport, Alexandria, Egypt.

Hallegatte, S.; Ranger, N.; Mestre, O.; Dumas, P.; Corfee-Morlot, J.; Herweijer, C. and Wood, R.M. (2011). Assessing climate change impacts, sea level rise and storm surge risk in port cities: a case study on Copenhagen. Clim. Chang., 104(1):113 - 137.

Hanson, S.; Nicholls, R.; Ranger, N.; Hallegatte, S.; Corfee-Morlot, J.; Herweijer, C. and Chateau, J. (2011). A global ranking of port cities with high exposure to climate extremes. Clim. Chang., 104(1): $89-111$.

Hasanean, H.M. (2001). Fluctuations of surface air temperature in the East Mediterranean. Theor. Appl. Climatol., 68 (1-2): 75-87.

Hazem, M.M. (1999). Adjective and diffusive processes affecting pollutants Along the Western Coast of Alexandria. M.Sc. Thesis, Faculty of Science, Alexandria University, Egypt.

IPCC (Intergovernmental Panel on Climate Change): Climate Change (2001). The Scientific Basis. Houghton, J.T.; Ding, Y.; Griggs, D.J.; Noguer, M.; van der Linden, P.J.; Dai, X.; Maskell, K. and Johnson, C.A. (eds.). Cambridge University Press, Pp: 881.

IPCC (Intergovernmental Panel on Climate Change): Climate Change (2007). The Physical Science Basis, Assessment Report of the Intergovernmental Panel on Climate Change. Solomon, S.; Dahe, Q.; Manning, M.; Chen, Z.; Marquis, M.; Averyt, K.B.; Tignor, M. and Miller, H.L. (eds.). Cambridge University Press, Cambridge, United Kingdom and New York, NY, USA.

IPCC (Intergovernmental Panel on Climate Change): Climate Change (2012). Managing The Risks of Extreme Events and Disasters to Advance Climate Change Adaptation. Field, C.B; Barros, V.; Stocker, T.F.; Qin, D.; Dokken, D.J. and Ebi, K.L. (eds.). Cambridge University Press, Cambridge, United Kingdom.

Maiyza, I.A.; El-Geziry, T.M.; Maiyza, H.I. and Kamel, M.S. (2011). Climatological trend of air temperature anomalies in the south-eastern Mediterranean Sea. Journal of King Abdul-Aziz University (JKAU), Mar. Sci., 22(2): 55-65.

Mariotti, A. (2011). Decadal Climate Variability and Change in the Mediterranean Region. US National Oceanic and Atmospheric Administration, Climate Test Bed Joint Seminar Series NCEP, Camp Springs, Maryland., Pp: 5. 
Metaxas, D.A.; Bartzokas; A. and Vitsas, A. (1991). Temperature fluctuations in the Mediterranean area during the last 120 years. Int. J. Climatol., 11: 897-908.

Oguntunde, P.G.; Abiodun, B.J. and Gunnar, L. (2012). Spatial and temporal temperature trends in Nigeria, 1901-2000. Meteorog. Atmos. Phys., 118: 95-105.

Repapis, C.C. and Philandras, C.M. (1988). A note on the air temperature trends of the last 100 years as evidenced in the Eastern Mediterranean time series. Theor. Appl. Climatol., 39: 93-107.

Sanchez-Arcilla, A.; Sierral, J.P.; Brown, S.; Casas-Prat, M.; Nicholls, R.J. ... et al. (2016). A review of potential physical impacts on harbours in the Mediterranean Sea under climate change. Reg. Environ. Chang., 16(8): 2471-2484.

Sierra, J.P.; Geniusa, A.; Lionelloc, P.; Mestresa, M.; Mössoa, C. and Marzoc, L. (2017). Modelling the impact of climate change on harbour operability: the Barcelona port case study. Ocean. Eng., 141: $64-78$.

Tonbol, K.M. and El-Geziry, T.M. (2015). The Daily SST Variations within the Southeastern Mediterranean Sea. Proceedings of the 12th International Conference on the Mediterranean Coastal Environment (MEDCOAST15), Varna, Bulgaria, Volume 2: 1005-1016.

Tonbol, K.M.; El-Geziry, T.M. and Elbessa, M. (2018). Evaluation of changes and trends in air temperature within the Southern Levantine basin. Weather 73(2): 60-66.

Tonbol, K.M.; El-Geziry, T.M. and Elbessa, M. (2019). Assessment of weather variability over Safaga harbour, Egypt. Arab. J. Geosci. 12: 805.

Turkes, M.; Sumer, U.M. and Demir, I. (2002). Re-evaluation of trends and changes in mean, maximum and minimum temperatures of Turkey for the period 1929-1999. Int. J. Climatol., 22: 947-977.

World Bank (2010). The costs to developing countries of adapting to climate change: new methods and estimates, Global report of the economics of adaptation to climate change study. The World Bank, Washington, U.S.A., Pp: 85.

\section{ARABIC SUMMARY}

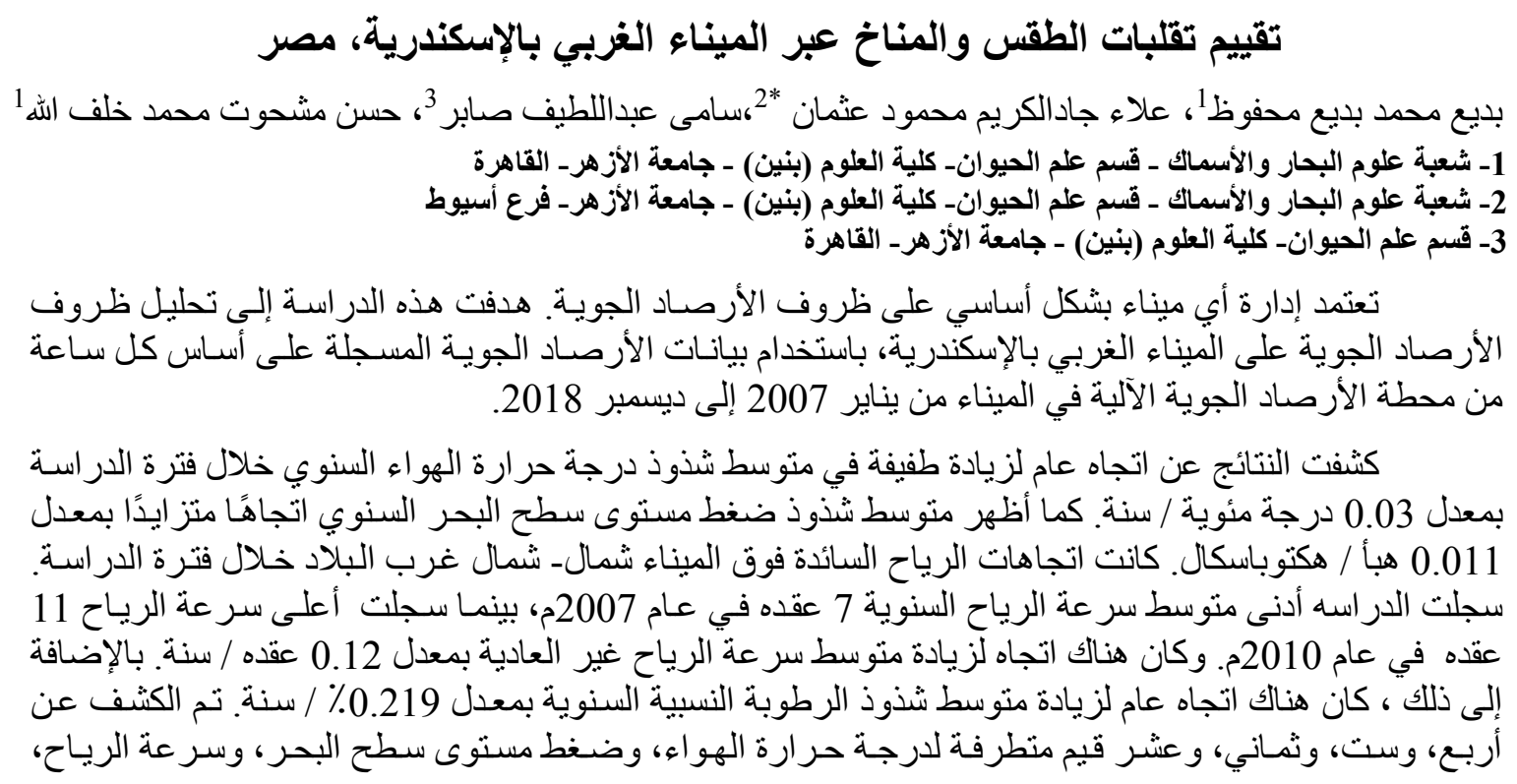


و الرطوبة النسبية، على التو الي. ومـع ذلك ، يجب أيضًا فحص المعلمـات الأوقيانو غر افيـة لتعزيز هذه النتائج. ومـع ذللك، ينبغي إعداد خطط التخفيف و التوعية وتنفيذها للتئ للميناء الغربي بالإسكندرية، مصر. 